\title{
The image of care delivery by Public Health Nurses as disseminated in Revista da Semana (1929)
}

\author{
Anna Karina de Matos Deslandes ${ }^{1}$ \\ Simone Aguiar ${ }^{1}$ \\ Mercedes Neto ${ }^{2}$ \\ Fernando Rocha Porto ${ }^{3}$
}

Objective: to analyze the images of Public Health Nurses in care delivery to society, disseminated by the Revista da Semana, in 1929. Method: historical-semiotic study. The documents used were images, to which an analysis matrix was applied, including fashion and body language literature, besides others to address the study object. The data were interpreted in the light of the sociologist Pierre Bourdieu's notions of object representations and body hexis. Results: the distinctive use of uniforms for the Public Health Nurses' activities was a non-verbal communication strategy to gain visibility and credibility during home visits. Conclusions: Public Health Nurses were particularly responsible for patient care and guidance to prevent illnesses, with a view to the qualitative development of Public Health. The intent in this study was to produce knowledge on image records about nurses' care practice at the National Public Health Department's School of Nurses, as well as to strengthen Public Health Nursing History research in Brazil, thus contributing to a better understanding about the construction process of nurses' image.

Descriptors: History of Nursing; Nursing Care; Public Health.

\footnotetext{
${ }^{1}$ MSc, Escola de Enfermagem Alfredo Pinto, Universidade Federal do Estado do Rio de Janeiro, Rio de Janeiro, RJ, Brazil.

2 Doctoral student, Escola de Enfermagem Alfredo Pinto, Universidade Federal do Estado do Rio de Janeiro, Rio de Janeiro, RJ, Brazil.

${ }^{3}$ PhD, Adjunct Professor, Escola de Enfermagem Alfredo Pinto, Universidade Federal do Estado do Rio de Janeiro, Rio de Janeiro, RJ, Brazil.
} 


\section{Introduction}

Different events in Brazilian and Nursing history marked the 1920's, including the Health Reform lead by Carlos Chagas and the implementation of the Modern Nursing model, through the National Public Health Department School of Nurses, currently Anna Nery School of Nursing, affiliated with Universidade Federal do Rio de Janeiro.

The Modern Nursing model started in the Federal District, which used to be Rio de Janeiro, funded by the Rockefeller Foundation, through a group of North American Nurses who were part of the Technical Cooperation Mission for the Development of Nursing in Brazil, which remained in the country between 1921 and $1931^{(1)}$

This model was set up through a number of strategies, including: the Emergency Course for the Visitadoras de Higiene (1921-1924) and the creation of the National Public Health Department School of Nurses to prepare Public Health Nurses, who would strategically replace the Visitadoras de Higiene during home visits after their graduation in $1925^{(2)}$.

In 1925, in São Paulo City, the Health Education Course was created, aimed at transforming primary education teachers into community health agents. Differently from Rio de Janeiro, health education did not involve the preparation of registered nurses, but granted the Visitadoras a central role in public health activities in São Paulo State. The aim was to disseminate notions and concepts of hygiene in the poor population, creating health awareness ${ }^{(3)}$.

Thus, in view of these strategies, the Revista da Semana published images on a full page, showing the Public Health Nurses at different moments during their care practice, including home visits, in the Federal District, in 1929.

Based on the above, this study is focused on the analysis of Public Health Nurses' images in care practice, through the publication in the Revista da Semana, with a view to analyzing the images of these Nurses in this printed media during care delivery to society.

This study is justified as it contributes to the construction of the Nursing image mechanism, as well as to care history as a social practice of the profession.

\section{Method}

This research was developed in the perspective of semiotic history, as it focused on image messages disseminated in their different social expressions, by penetrating the universe of representations and identifying and unveiling influences and interrelations and mechanisms of the social groups involved(4).

Although six photographic images were published on a single page in the Revista da Semana, located in the Rio de Janeiro National Library, this study was focused on only five, which were centered on the nurses and circumstances - care delivery, all of them accompanied by the main title "the Missionaries of Charity".

It should be highlighted that Ethel Parsons' role was excluded from the analysis due to the methodological criterion establish, although this North American nurse should be discussed in view of her great importance for Brazilian Nursing, considering her leadership in the implementation of Modern Nursing in the Federal District, implemented in Brazil over the years.

The article published in the Revista da Semana looked at care practice, especially at home, by Public Health Nurses from the National Public Health Department School of Nurses.

To analyze the images, an analytic matrix was applied, consisting of four pairs. The first relates to the registering of the photograph's identification data; the second to data from the expression level; the third to data from the content level, and the fourth to complementary data obtained from other photographs ${ }^{(4)}$.

The expression level refers to the manifestation of contents from the verbal, non-verbal or syncretic signification system. The content level, on the other hand, relates to the meaning of the test, as it is called in semiotics, to what the text says and how it says what it does from a semiotic perspective(5).

To decode the images' symbolic elements in the news item, literature was used about the body image, History of Fashion and Nursing History. In addition, documents from the Documentation Center at Anna Nery School of Nursing were also used, discussing the Nurses' practical activities and uniform use at that time.

These documents were triangulated and interpreted in the light of the French sociologist Pierre Bourdieu's notion, choosing the object representations and body hexis as central for the study.

The presentation of the results and discussion were grouped, as the analytic product of the five images and their respective legends, and organized in two subtitles, which were: the Uniform of Public Health Nurses and Care Delivery by Public Health Nurses.

The images used in this study are in the public domain, according to Law 9.610/1998, which addresses copyright on the authorization, update and consolidation 
of copyright and other determinations, considering chapter III, articles 43 and 44 and chapter IV, article 46, paragraphs I and $\operatorname{III}^{(6)}$.

\section{Result and Discussion}

The School of Nurses, affiliated with the National Public Health Department (DNSP), with funding from the Rockefeller Foundation, served as the institutional context for Public Health Nurses' education, since the start of its activities in 1923. Deans of the School were the North American nurse Clara Louise Kieninger in 1923-1925, followed by Nurse Loraine Geneviéve Denhardt in 1925-1928. Funding from the Rockefeller Foundation was expected to end in 1928 but, as a result of special circumstances agreed upon with the Brazilian government, was extended until 1931, when the North American nurse Bertha Pullen was the Dean of the educational institution(1).

In the same period, the Revista da Semana published the subject entitled "The missionaries of charity" on a full page in 1929, including six images with legends (Figure 1).

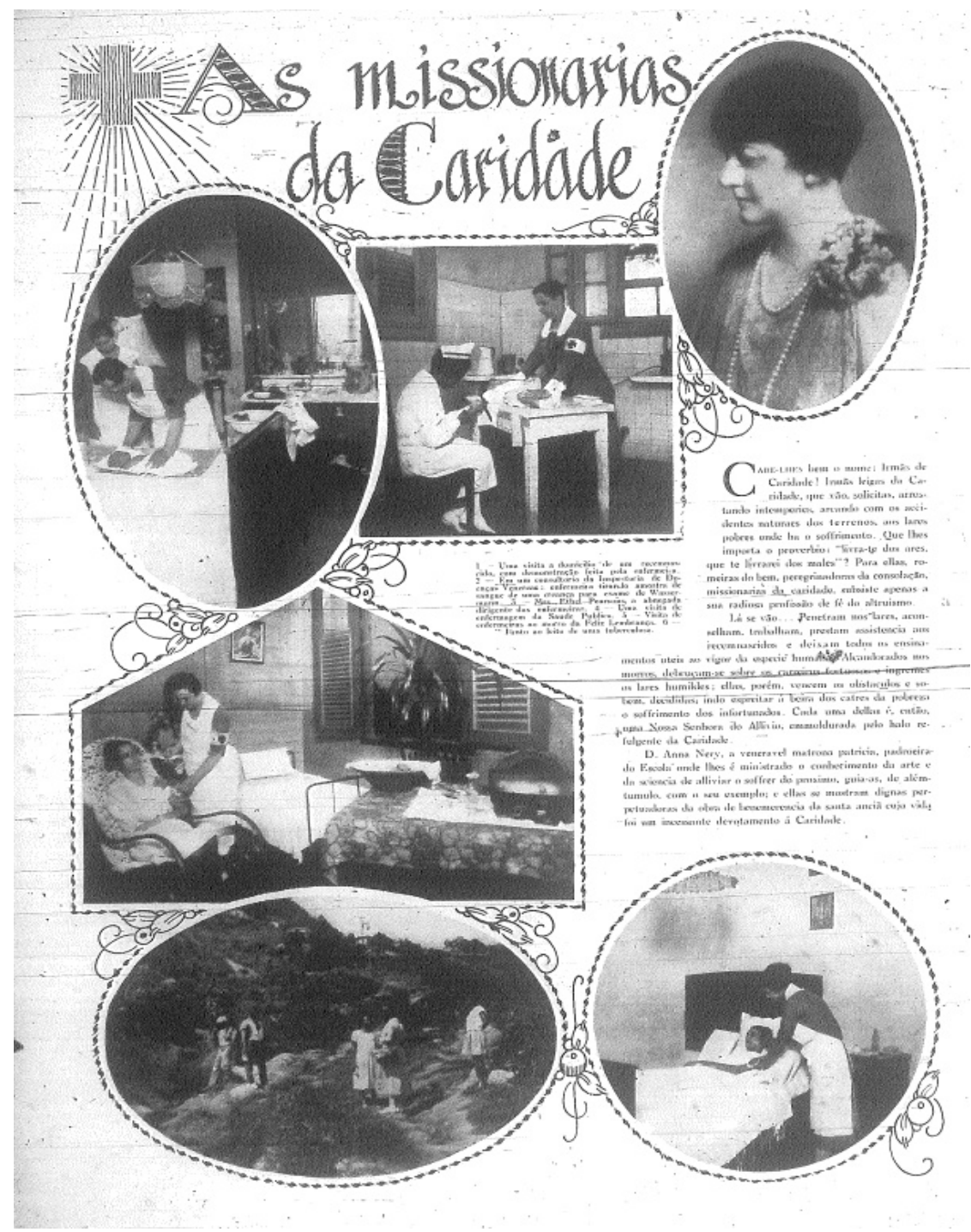

Figure 1 - Facsimile, published on March 23 ${ }^{\text {rd }} 1929$, in the Revista da Semana, entitled "The Missionaries of Charity".

When decoding the title of the article "The missionaries of charity", considering the meaning at that time, the word "missionary" is related to preaching faith; to missions; and the word "charity" means love to fellow beings, benevolence, beneficence(7).
It is clear that the readers of this news item understood that the Public Health Nurses were missionaries in a noble and essential profession to provide the population with better health conditions, as understood from their teachings on population health. 
In other words, when sent to the homes to educate the families and practice health promotion actions, related to rest, good eating and ventilation, the nurses reproduced care as one of the strategies for the credibility of the Health Reform.

\section{Uniform of Public Health Nurses}

In short, the images published on the page of Revista da Semana are momentary flashes, with different geometric formats - irregular, squared and oval, in varying shades of grey, mostly in female groups and in a natural context, whether at home or in external areas.

On the five images analyzed, the Nurses wear two types of uniforms. One was the dark grey long-sleeved uniform with light-colored cuffs, collar and bracers, highlighting the dark cross symbol. Some nurses wear a light-colored apron, showing a valise and a hat.

The likelihood of the Nurse's grey-colored uniform on the image, based on documents consulted at the Anna Nery School of Nursing Documentation Center, was found in tissue color records, referring to greyish $\operatorname{color}^{(8)}$.

The greyish tissue color, from a fashion perspective, translates that it means refined class and efficiency. In this perspective, using a de luxe tissue light or darkgrey colored suit indicates economic and social ascent and means power ${ }^{(9)}$. This reveals that the DNSP Nurses transmitted credibility in their function, which probably justifies the color of their uniform.

In summary, it can be affirmed that the Nurses' uniform in care practice consisted of: a long-sleeved jacket with white cuffs and collars and a skirt at thirty centimeters from the floor; a belt attached to the jacket with two buttons on each side, a black straw hat with brim and a plain black ribbon around the crown; the shoes were white and the stockings silk. In addition, they carried a black leather valise with the material they needed in their activities ${ }^{(10)}$.

Despite the images published in Revista da Semana, some details cannot be identified, except for the use of the apron when delivering direct patient care.

The uniform shown is similar to that of the DNSP Visitadoras de Higiene, from the Emergency Course, who were replaced by the Public Health Nurses after their graduation in 1925, considering that the Visitadoras' course ended in 1924.

This likelihood may have been a strategy of what had already been acknowledged as legitimate, and was easily identified by society, also considering the credibility of the work the DNSP Visitadoras de Higiene developed.

In addition, they showed a bracer with the symbol of the cross, which suggests similarity with that of the Brazilian Red Cross Nurses, also entailing the same symbolic representation of fight for the needy ${ }^{(1)}$.

These inferences rest on the dignity and power other social agents had conquered earlier, through the object representations, composed of representative symbols, and which justifies the orders issued on their behalf. Authority is but credit in a group of agents who constitute relations. The more precious these relations are, the greater the credit they benefit from themselves ${ }^{(11-12)}$

Another type of long-sleeved, light-colored uniform was made, including a cap with a dark ribbon and light-colored shoes, used by the registered Nurse described in another study ${ }^{(1)}$ and once again ratified in a document located at the Anna Nery School of Nursing Documentation Center. This uniform was used in Hospital Service and made out of white cotton, distinguished from the Nurses working in practice areas who wore grey uniforms ${ }^{(13)}$.

The symbolic function of the uniform should be highlighted, which since education marked the different course phases: new students exchanged their preliminary uniforms for that of junior students; in the final course phase, they changed their hospital uniforms for that of the public health nurse. The teachers and Nurses were identified and distinguished by their uniform, generally used a hospital uniform with cap and ribbon, while the DNSP nurses used their private uniforms and the white bracer $^{(14)}$.

The distinctions between these uniforms were marks that can be considered as likely symbols of the activities performed in the hospital context and during home visits.

\section{Care Delivery by Public Health Nurses}

The care disseminated in the Revista da Semana can be considered as: newborn care, test material collection, blood pressure verification, comfort and orientations, totaling five activities.

The first relates to care delivered to an infant and supposedly observed by the mother, with the legend "A visit to the home of an infant, with demonstration by the nurse".

In this care action, the Nurse demonstrates how to proceed with the child to the other woman. In their Practice Areas, the Nurses from the National Public Health 
Department School of Nurses undertook two kinds of home visits. The first was a surveillance visit, when they gave advice and hygiene and prophylaxis instructions, without delivering direct care; and the second was known as a Care Visit, which involved different services the nurse performed at the - adult or child - patient's home, related to hygiene, physical examination, meal preparation and other relevant care activities ${ }^{(15)}$.

Another type of care disseminated through the images relates to the legend "At a consultation room of the inspector's office for venereal diseases: nurse taking a blood sample from a child for the Wassermann test". This squared photograph shows one Nurse wearing a light-colored uniform, one child and another Nurse wearing a grey uniform.

The legend indicates that the Nurse was collecting a blood sample for the Wassermann test. This test was performed to diagnose syphilis, and is named after the German physician August Paul Von Wassermann, who created the test. The environment shown is the consultation room of the inspector's office for venereal diseases, an institutional area where the Public Health Nurses were active, where the disease was diagnosed and treated.

It is identified on the image that the Nurse wearing the light-colored uniform collects the blood sample from the child, while the Nurse in the dark-colored uniform holds the child in the right position. As the picture was taken at the inspector's office for venereal diseases, the uniform worn should be dark instead of light-colored, as the latter is used in the hospital context.

Some hypotheses can be established, including the possibility that the nurse in the light-colored uniform was one of the instructors of the aspirant nurses present at the inspector's office; or that she was a head nurse/ supervisor at the inspector's office, distinguished by her uniform and especially by the cap with the dark ribbon, which only registered nurses used.

The third care image the Revista da Semana published displayed the Public Health Nurse performing some procedure on a patient, who was sitting in a chair at home. This image came with the legend "A public health nursing visit".

The woman sitting down has her arms resting on her abdomen. This body position indicates a social protection barrier that, in combination with the folded hands, indicates inattention to what she was hearing ${ }^{(9)}$. On the other hand, the seated woman's position can also be understood, according to the care context, as the position to check blood pressure for example.
According to this hypothesis, the patient's left arm is involved in an object, which seems to be the cuff of the pressure device. Departing from this viewpoint, the Nurse's right hand seems to be trying to adjust the equipment. Some readers may be wondering: Would this not be the chest piece of the stethoscope?

The response to this inquiry, based on the consulted documents, guided the answer and signaled the weakness of the hypothesis about the nurse checking the seated woman's blood pressure, as the list of materials the nurse was carrying in her valise did not mention the pressure device and stethoscope ${ }^{(15)}$.

In addition, the excerpt on the care nurses are supposed to deliver indicates that one of the aspects they needed to register should be: Temperature, Pulse and Breathing (TPB). Blood pressure verification was not included as a nursing procedure though ${ }^{(15)}$.

Another aspect that supports this consideration about the inquiry and weakness of that hypothesis is the fact that most adults whom the Public Health Nurse visited were tuberculosis patients. This disease affected the poorer population and, therefore, the popular use of that material in the home context at that time seems to be hard to believe ${ }^{(15)}$.

It is highlighted that, in 1916, the physician Getúlio dos Santos, professor and dean of the School of Practical Nurses of the Brazilian Red Cross, wrote a manual for Nursing professionals entitled "The Book of the Male and Female Nurse for use by people Working in the Profession and People who take Care of the III", which was re-issued in 1926 and 1928. In the book, some relevant aspects for the profession are described, including the Nurses' responsibility to check patients' vital signs - TPB, but without permitting stethoscope use for blood pressure verification, which should be done through touch(16).

One possible interpretation is that the use of the pressure device as a form of assertion may be close to the truth. In other words, despite signals that the nurse was using the blood pressure device as a form of care support technology, this may be a form of analytical imprudence. The same is true with regard to stethoscope use, arousing other inquiries, to be addressed in research on the trajectory of care, which for now is lacking further elaboration and the construction of theoretical hypotheses.

The next image in the Revista da Semana shows a Nurse wearing a "full" dark-colored uniform, in an open and natural situation, which according to the selfexplanatory legend shows a "Visit by nurses to the Morro da Feliz Lembrança". 
The body hexis the nurse adopted on the image is standing, with her head turned towards the woman addressed, as if she is talking. The woman addressed is also standing, with her head turned towards the nurse, as if she is watching and listening attentively. This woman has her arms stretched along her body, reminding of the same position the military adopt and which may indicate attention.

The woman's feet are turned towards the nurse. Based on her body language, one can infer that her feet can symbol her attention to the nurse's conversation, orientation or inquiry. On the opposite, the nurse's feet are turned more to the front, at a right angle towards the woman's feet. This may mean that she wanted attention from the people around her, as this body position tends to transmit opening and availability in communication ${ }^{(9)}$.

The last image published in Revista da Semana shows a nurse taking care of a bedridden tuberculosis patient, according to the legend "At the bedside of a tuberculous woman".

The Nurse's body hexis is standing, with her body curved towards the patient. This position suggests care delivery at the moment the photograph was taken, which can be decoded as concentration on what she is doing, considering the direction of her look and her bending over the woman, who is lying down with her arms resting on her body(2).

The position of the patient's arm on the image suggests that she tries to protect herself from any manipulation in bed, indicating insecurity, fear or discomfort. In addition, the patient is covered by bed sheets, indicating some degree of confinement, in line with possible insecurity, fear or discomfort caused by the manipulation of her body ${ }^{(9)}$.

The tuberculous woman's arm is involved in something. As the image is not very clear, even when zoomed in - an informatics tool - this personal attribute could not be decoded.

Another relevant highlight is the aim of the visit to tuberculosis patients, that is, to help them to avoid spreading the disease to adjacent areas and, hence, around Brazil.

Moreover, the Nurse was responsible for identifying and monitoring patients with tuberculosis symptoms, forwarding them when necessary for examination to medical consultations or the medical clinic of the tuberculosis inspector's office, located closer to the patient's home. In addition, she was responsible for asking people, mainly children, who had been in direct or indirect contact with tuberculosis patients to be examined by the family doctor or medical clinician every three months ${ }^{(17)}$.

\section{Conclusion}

As a result of this study, based on the analysis of the images of Nurses published on a full page of the Revista da Semana, the importance of their work cannot be denied, ratified by the direct or indirect cost of the article, as well as some lay-out and text analysis aspects, which lacked analysis and discussion, motivated by methodological rigor.

By respecting the proposed study design, in summary, the message the Revista da Semana disseminated to its readers was that Public Health Nurses were particularly responsible for care delivery to the ill and for guidance to prevent illnesses, promoting health in the role of educators, with a view to developing the quality of Public Health.

In the same sense, the distinction between the object representations for each type of activity the Public Health Nurses performed was evidenced, as a non-verbal communication strategy.

This strategy was considered a facilitator of the Nurses' interventions in the home context, which the Revista da Semana made visible, as most of the images were made at home, and credible, through the body hexis in care delivery to society.

At that time, this may have resulted in enhanced credibility towards society and may have aroused young women's aspirations to become Nurses, considering the work of the DNSP School of Nurses.

Based on the above, difficulties existed, whether in the nurses' education, in the professionalization process, in the fight against tuberculosis, among others. In one of the issues of Revista da Semana during the implementation process, however, Modern Nursing had its power and prestige disseminated on a full page, when compared to other health professionals like Registered Midwifes for example. But that is material for another study.

\section{References}

1. Santos TCF, Lopes GT, Porto F, Fonte AS. Resistência à Liderança Norte-Americana na Formação da Enfermeira Brasileira (1934-1938). Rev. Latino-Am. Enfermagem. [periódico na Internet]. jan-fev 2008 [acesso $20 \mathrm{dez}$ 2011]; 16:130-5. Disponível em: http://www.scielo.br/ pdf/rlae/v16n1/pt_19.pdf. 
2. Porto F, Santos TCF. O Rito e os Emblemas na Formatura das Enfermeiras Brasileiras no Distrito Federal (19241925). Esc Anna Nery. 2009 abr-jun;13(2):249-55.

3. Santos LAC, Faria LR. A Cooperação Internacional e a Enfermagem de Saúde Pública no Rio de Janeiro e São Paulo. Horizontes. jul/dez 2004;22(2):123-50.

4. Mauad AM. Sob O Signo da Imagem: A Burguesia Carioca (1900-1950). A Margem. 1993;1(1):5-15.

5. Fonseca EFR, Porto F. Fac-símile na pesquisa em História da Enfermagem Obstétrica: Inauguração da capela da Pró-Matre (1923). Rev Pesq Cuid Fundam. [periódico na Internet]. out-dez 2010 [acesso $10 \mathrm{dez}$ 2011]; 2:1495-505. Disponível em: http://www. seer.unirio.br/index.php/cuidadofundamental/article/ view/1315/pdf_236

6. Lei 9.610, de 19 de fevereiro de 1998 (BR). Altera, atualiza e consolida a legislação sobre direitos autorais e dá outras providências. 1998. [acesso 12 jan 2012]. Disponível em: http://www.planalto.gov.br/ccivil_03/ leis/L9610.htm

7. Figueiredo C. Novo Diccionário da Língua Portuguesa. $3^{a}$ ed. Lisboa: Sociedade Editora Portugal-Brasil; 1922. $1048 \mathrm{p}$.

8. Departamento Nacional de Saúde Pública (BR). Serviço de Enfermeiras. O uniforme da enfermeira de saúde pública. Rio de Janeiro (RJ): Escola de Enfermagem Anna Nery, Centro de Documentação da Universidade Federal do Rio de Janeiro; 1926. mod. A, cx. 10, doc. 104 .

9. Porto F, Fonseca, EFR. Enfermeiras-Parteiras e Uniforme: Indícios e Representações Objetais na construção da identidade profissional. Rev Enferm UERJ. jul/set 2011;19(3):432-7.

10. Fallante BSC, Barreira IA. Significados da visita domiciliar realizada pelas enfermeiras de saúde pública nas décadas de 20 e 30. Esc Anna Nery. 1998;2(3):72-86. 11. Bourdieu P. Coisas Ditas. São Paulo: Brasiliense; 2004. 234 p.

12- Bourdieu P. Razões práticas: sobre a teoria da ação. $4^{a}$ ed. Campinas: Papirus; 1996. 224 p.

13. Departamento Nacional de Saúde Pública (BR). Serviço de Enfermeiras. O uniforme utilizado no serviço hospitalar. Rio de Janeiro (RJ): Escola de Enfermagem Anna Nery, Centro de Documentação da Universidade Federal do Rio de Janeiro; 1927. mod. A, cx. 11, doc. 08. 14. Peres MAA, Barreira IA. Significado dos uniformes de enfermeira nos primórdios da enfermagem moderna. Esc Anna Nery. 2003;7(1):25-38.
15. Departamento Nacional de Saúde Pública (BR). Serviço de Enfermeiras. Zona de Prática. Rio de Janeiro (RJ): Escola de Enfermagem Anna Nery, Centro de Documentação da Universidade Federal do Rio de Janeiro; 1928. mod. A, cx. 16, doc. 171.

16. Santos GF. O livro do enfermeiro e da enfermeira. $3^{a}$ ed. Rio de Janeiro: CVB; 1928. 376 p.

17. Departamento Nacional de Saúde Pública (BR). Serviço de Enfermeiras. Plano de palestra sobre a tuberculose. Rio de Janeiro (RJ): Escola de Enfermagem Anna Nery, Centro de Documentação da Universidade Federal do Rio de Janeiro; 1925. mod. A, cx. 7, doc. 92. 